UDC 330.366:65

DOI: https://doi.org/10.32840/2522-4263/2021-1-8

Trusova Nataliia

Doctor of Economics, Professor,

Professor of Finance, Banking and Insurance Department Dmytro Motornyi Tauria State Agrotechnological University

Prystemskyi Oleksandr

Doctor of Economics, Associate Professor, Professor of Accounting and Taxation Department Kherson State Agrarian and Economic University

Tрусова H.В.

доктор еконолічних наук, професор, професор кафедри фінансів, банківської справи та страхування Таврійського державного агротехнологічного університету ілені Длитра Моторного

Пристемський О.C. доктор еконолічних наук, доцент, професор кафедри обліку і оподаткування

Херсонського державного аграрно-еконолічного університету

\title{
ENSURING THE SUSTAINABILITY OF THE POTENTIAL OF THE LOSS-FREE DEVELOPMENT OF AGRICULTURAL ENTERPRISES
}

\section{ЗАБЕЗПЕЧЕННЯ СТІЙКОСТІ ПОТЕНЦІАЛУ БЕЗЗБИТКОВОГО РОЗВИТКУ СІЛЬСЬКОГОСПОДАРСЬКИХ ПІДПРИЕМСТВ}

\begin{abstract}
ANNOTATION
The article deals with the potential of the loss-free development, which forms the system of financial protection of vital interests of subjects of the agrarian sector through the guarantee of food security in the long-term. It is proved that under the pressure of the external environment, leverage and financial mechanism tools that trigger the potential of the loss-free development of agriculture can change, risk manifestation and economic depression of enterprises continue or stop. The priority of financial support of agriculture of Ukraine according to indicators of intensity and efficiency of use of financial resources is singled out. A comprehensive indicator of potential of the loss-free development is proposed. The model is adequate, its statistical quality, significance and reliability are sufficient for forming the forecast level of potential of the loss-free development of agrarian enterprises of the region.
\end{abstract}

Key words: potential, financing, financial resources, breakeven, agriculture, agricultural enterprises.

\section{АНОТАЦІЯ}

У статті розглядається формування стійкого потенціалу беззбиткового розвитку сільськогосподарських підприємств, що формує систему фінансового захисту життєво важливих інтересів суб'єктів аграрного сектору шляхом гарантування продовольчої безпеки в довгостроковій перспективі за рахунок репродуктивного рівня фінансової підтримки. Доведено, що під тиском зовнішнього середовища інструменти важелів та фінансових механізмів, що ініціюють потенціал беззбиткового розвитку сільського господарства, можуть змінюватися, прояви ризику та економічна депресія підприємств продовжуються або припиняються. Важливість формування сукупної вартості потенціалу розвитку без втрат у регіоні зумовлена його складовою, яка здатна виконувати дії з мобілізації реальних та прихованих можливостей фінансових ресурсів за обмежений проміжок часу, для подолання загрози безпечному середовищу для функціонування аграрних підприємств. Виокремлено пріоритет фінансової підтримки сільського господарства України за показниками інтенсивності та ефективності викорис- тання фінансових ресурсів. Запропоновано комплексний показник потенціалу беззбиткового розвитку. В регіонах України використовується диференційований підхід до кластеризації показників фінансових ресурсів як взаємозалежність факторів формування сукупної величини потенціалу беззбиткового розвитку аграрних підприємств. За допомогою індуктивного системного аналізу розроблена модель стабільного рівня потенціалу спроможності фінансового забезпечення на основі чистого прибутку. Модель адекватна, її статистична якість, значимість та надійність $€$ достатніми для формування прогнозного рівня потенціалу беззбиткового розвитку аграрних підприємств регіону. Розроблена методологія базується на складових захисту фрінансової системи суб'єктів господарювання в умовах обмежень вибору альтернативних джерел формування та розподілу фінансових ресурсів, а також на ймовірності їх використання. Запропоновані шляхи ефективного функціонування механізму державного регулювання, що дасть змогу відновити та підтримувати на належному рівні продовольчу незалежність країни.

Ключові слова: потенціал, фінансування, фінансові ресурси, беззбитковість, сільське господарство, аграрні підприємства.

\section{АННОТАЦИЯ}

В статье рассматривается потенциал обеспечения устойчивости потенциала безубыточного развития сельскохозяйственных предприятий, формирует систему финансовой защиты жизненно важных интересов субъектов аграрного сектора путем обеспечения продовольственной безопасности в долгосрочной перспективе за счет репродуктивного уровня финансовой поддержки. Доказано, что под давлением внешней среды инструменты влияния и финансового механизма могут меняться. Выделены приоритет финансовой поддержки сельского хозяйства Украины по показателям интенсивности и эффективности использования финансовых ресурсов. Предложен комплексный показатель потенциала финансирования сельскохозяйственных предприятий. Разработанная модель стабильного уровня потенциала способности финансового 
обеспечения на основе чистой прибыли, которая базируется на составляющих защиты финансовой системы субъектов хозяйствования в условиях ограничений выбора альтернативных источников формирования и распределения финансовых ресурсов.

Ключевые слова: потенциал, финансирование, финансовые ресурсы, безубыточность, сельское хозяйство, аграрные предприятия.

Formulation of the problem. Under conditions of financial instability, economic contradictions and objective inevitability of processes and phenomena, there are prerequisites and needs in the sources of agricultural financing, which is characterized by specifics of relations with financial institutions to strengthen investment activities, improve the safe environment of agricultural enterprises. At the same time, the fundamental foundations of modern financial thought do not allow to put an end to the study of the state of irrational financial management and fractality of problem areas of financing potential of economic entities given the growing dependence of the state on debt.

The analysis of recent research and publications. The concept of ensuring the sustainability of the potential of the loss-free development of agriculture in the context of financial activities of agricultural enterprises is considered by foreign scientists W. Coleman, G. Skogstad, M. Atkinson, B. Forgue, C.-H. Ling, H.-L. Yang, D.-Y. Liou, W. Moyer, T. Josling, M. Petrickas a regulatory function of the loss-free development of economic entities with justification of the principles of their sustainable operation; by O. Zhydyak, V. Korneev, T. Kuzenko - as an assessment of the distributive level of funding for the industry and the strategy of the loss-free development of agricultural enterprises in the regions; by O. Baranovsky, M. Yermoshenko, N. Davydenko, N. Prokopenko, S. Frunza, V. Tsybok - as a priority of ensuring national and individual interests of subjects by overcoming economic contradictions, formation of effective capital and state control over its use, formation of macro- and microeconomic stability.

Formulation of the goals of the article. To consider the economic aspect of the sustainability of the potential of the loss-free development of agricultural enterprises with the priority of financial support for agriculture in the state.

Presenting the main material. Unfortunately, in Ukraine there is a lack of targeted funding due to small amounts of budget funds to support the development of the industry, budget imbalances, lack of own funds of agricultural enterprises, their inability to attract bank loans [1]. This encourages the transformation of market regulators of agricultural financing and ensuring a stable business environment for enterprises through the efficient use of corporate resources. We believe that the problem of financing agricultural enterprises in modern conditions is manifested in the economic performance of the industry, financial condition of entities, their solvency, payment discipline, changes in financing structure, reducing the competitiveness of the industry and weakening the position of farmers in forming food security, despite the growing level of profitability of the main activity in recent years. Therefore, there is a need to develop a model to ensure the stable potential of the loss-free development of agricultural enterprises, given the imbalances and risks of the reproduction process of the industry.

From the standpoint of the external environment influence, the potential of the loss-free agricultural development forms a system of financial protection of vital interests of the industry entities (guaranteed food security in the long run) through a reproducible level of funding (sources of financial resources). This reduces the level of threat to business entities in the conditions of risk. Under the pressure of the external environment, the levers and instruments of the financial mechanism, which activate the sustainable potential of the loss-free development of agricultural enterprises, may change; the manifestation of risk and economic depression of economic entities may continue or be suspended. At the initial stage of the spread of foreign economic destabilization, the risk is manifested in the case when the financing of the resource component of the sustainable potential of the loss-free development of agricultural enterprises is rapidly deteriorating and the amount of credit resources is reduced. The most widespread is the mechanism, the sequence of implementation of which in a simplified form is shown in Fig. 1.

Thus, the destabilization of financing leads to a reduction in the inflow of financial resources in agriculture and the mass withdrawal of previously made investments. The consequence of the reduction of credit resources is the strengthening of requirements for the condition and reliability of borrowers. This external factor causes a decrease in the creditworthiness of agricultural enterprises as the most risky. At the same time, credit rates are rising, which makes it even more difficult for borrowers to attract sources of forming the financial resources [2].

The decline in the creditworthiness of agricultural enterprises during the period of greatest increase in the impact of risk, on the one hand, and the rise in price of loans on the other, leads to limited funding and the risk of financing [3]. At the same time, investments and current expenditures on protection and rational use of natural resources in agriculture are reduced [4]. The result of the above processes is the reduction in income and deterioration of the activity results of agricultural enterprises, which provokes the risk of profitability, and further, due to lack of financial resources it influences the resumption of the next production cycle, which leads to increased solvency risk [2].

Another variant of the impact of financing risk on the sustainable potential of the loss-free 


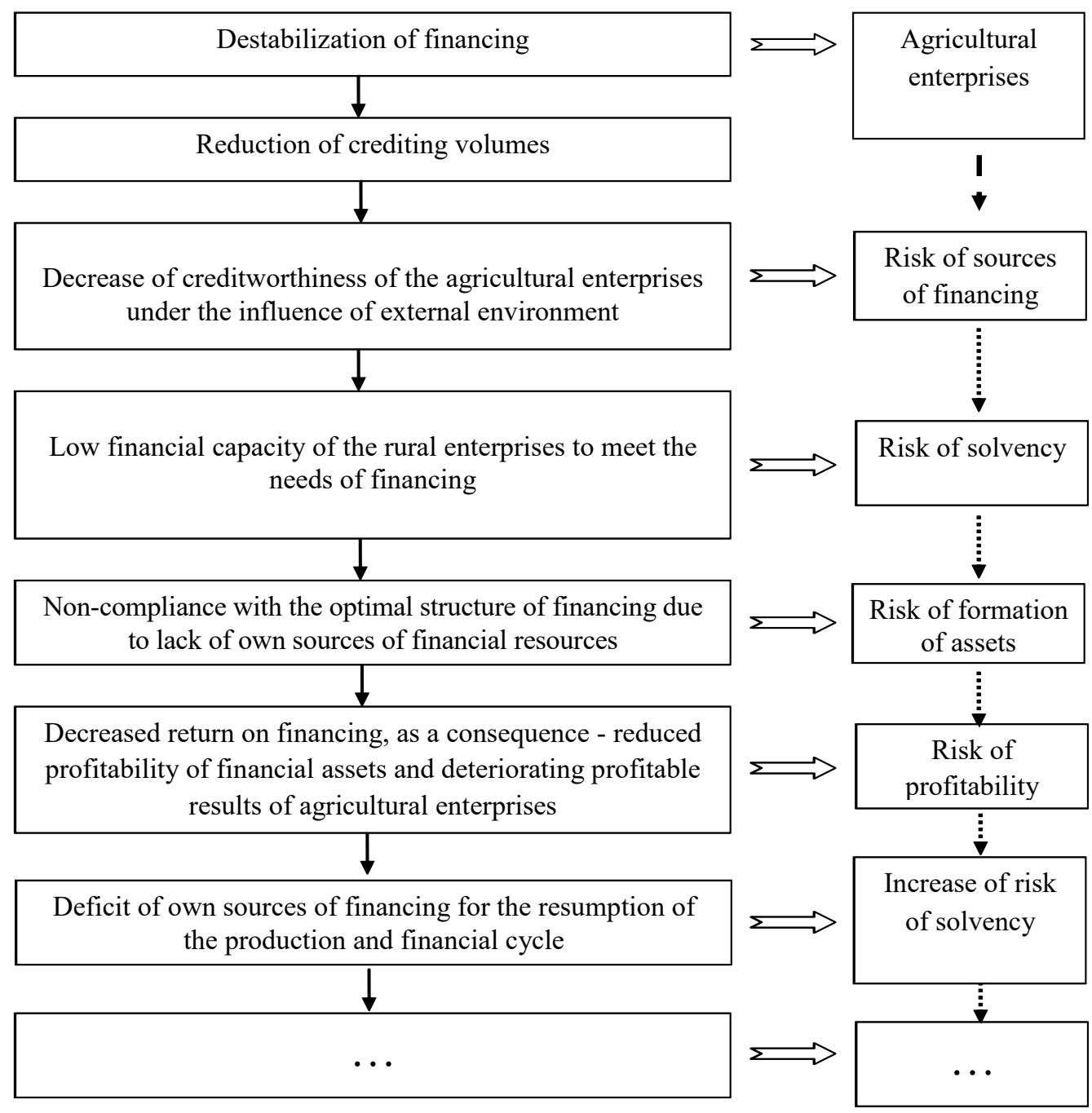

Fig. 1. Manifestations of the impact of destabilization of financing on the sustainable potential of the loss-free development of agricultural enterprises

Source: improved by the author based on data [2]

development of agriculture is the result of destabilization of the money market and intensification of inflation processes. The most obvious ways to minimize it is to reduce the monetization of assets of agricultural enterprises (Fig. 2).

This phenomenon is known in practice as an "escape into real assets". However, if this protective mechanism is applied, the optimal structure of financial resources is violated, which makes it impossible for agricultural production to be profitable and causes the risk of asset formation [2].

Lack of cash complicates settlements with suppliers, creditors, employees and leads to the risk of solvency of agricultural enterprises. Ultimately, the maneuverability of own sources of forming the financial resources is reduced and destabilizing manifestations are intensified. In addition, the accumulation of excessive current assets requires an increase in financial costs for their storage, which causes losses and, ultimately leads to the risk of profitability.

The sustainable potential of the loss-free development of agricultural enterprises forms the correlation of agricultural and financial policy of the country, provides general and specific principles of state policy in the field of strengthening the economic development of the country. The first ones include the priority of human and civil rights and freedoms; priority of ensuring national interests; legality, unity, etc.; the second - overcoming financial contradictions and balancing individual and national interests, formation of effective distribution of financial resources and capital and state control over their use, formation of macro- and microfinance stability $[5 ; 6]$.

Methodological features of ensuring the sustainable potential of the loss-free development of agriculture and its specific manifestation is the objective basis that should be taken into account when assessing the safe environment of functioning of agricultural enterprises, justifying economic incentives, determining forms of financing and areas of intensive and efficient use of financial resources. This provision is fundamentally important in terms of increasing the capacity of agriculture, strengthening its position in 


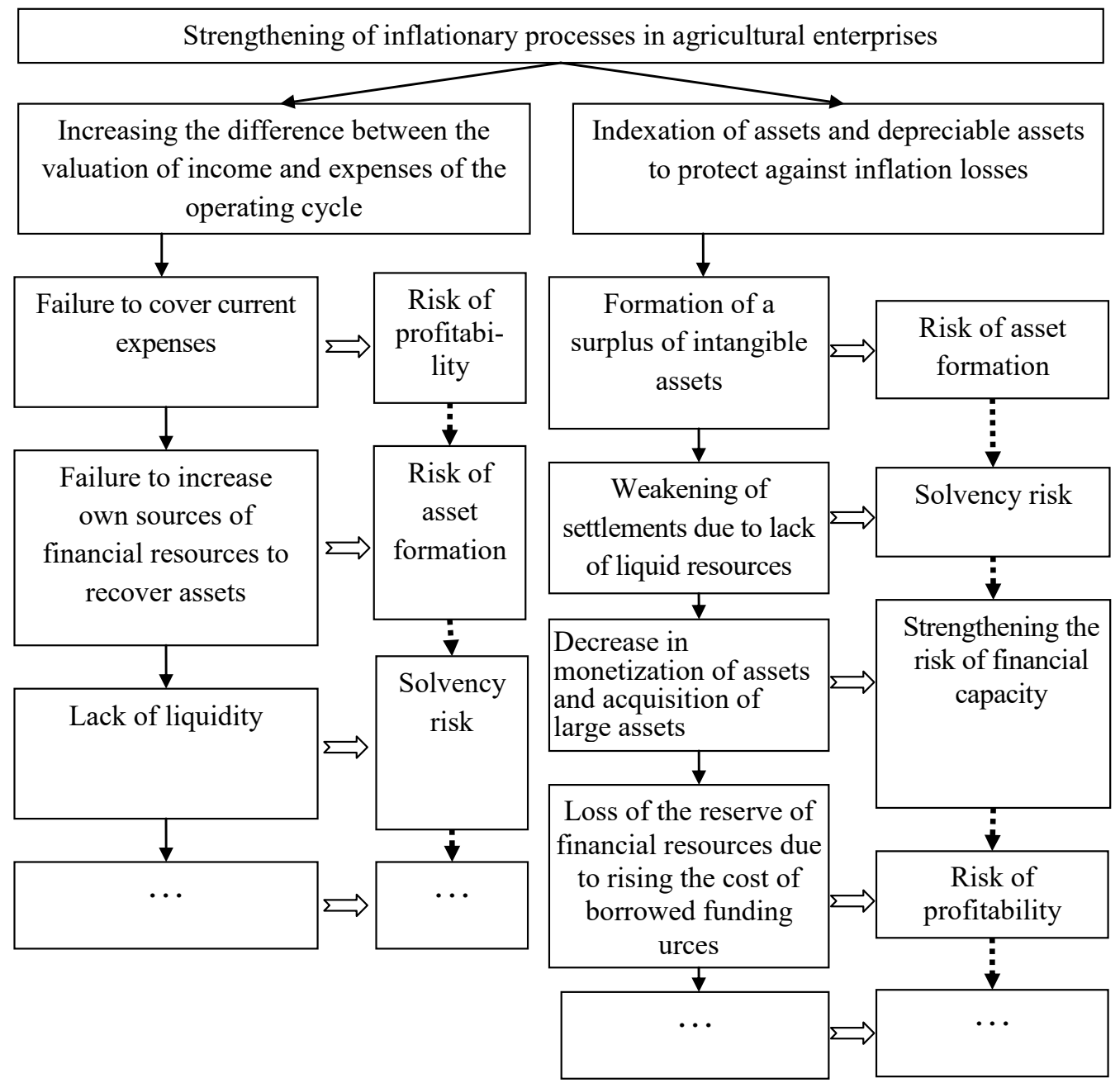

Fig. 2. Manifestation of the impact of money market destabilization and rising inflation on the sustainable potential of the loss-free development of agricultural enterprises Source: improved by the author based on data [2]

the world market in order to form a certain level of stability, improving the conditions of use of existing and accumulated financial resources of entities $[5 ; 7 ; 2]$.

The study of the sustainable level of the lossfree development of agricultural enterprises is based on the ability to counteract the risks in agriculture and provides a comprehensive study of financing, which should be conducted in two directions. The first area of research is related to the study of external threats to the safe environment of agricultural enterprises in the context of the analysis of their financial condition and risks. It aims to assess the emergence of an unstable environment in agriculture as a whole. The second direction of the study is to assess the regional aspects of the risk-free environment of functioning of agricultural enterprises, to determine indicators of their stability, independence, profitability, liquidity in the long run and risks of functioning, taking into account the territorial features of their location [2].

The need for the first of the identified areas of research is caused by the fact that agriculture in Ukraine is one of the leading areas of the economy, the development and efficiency functioning of which directly affects the state of sustainability of the potential of the loss-free development of the state. Any changes in the structure of agricultural financing immediately provoke a threat to the safe environment of functioning of agricultural enterprises. Moreover, the dynamics of negative trends in agriculture affects the lengthening of production, operational and financial cycles of economic entities, their inertia, inability to quickly adapt to the dynamic pressure of a significant number of threats to the level of financial security. Therefore, it is necessary to study the trends of sustainable and loss-free development of agriculture in general, as well as to assess such trends [5; $7 ; 2]$.

The implementation of the second direction of the analysis is related to the assessment of structural and regional aspects of ensuring the sustainable potential of the loss-free development of agricultural enterprises. Since the territorial location plays a decisive role in the efficiency of the entities, the financing processes in the region 
have a more significant impact on the financial results of agricultural enterprises than the whole complex of economic relations within the economic system of the entity. In view of this, an important component of ensuring the sustainable potential of the loss-free development of agricultural enterprises in the context of sectoral priorities is government regulation, which helps to monitor government support and determine criteria, parameters and indicators of sustainable financing of industrial activities at the institutional, regional and micro levels. The regulatory function of the state embodies the limit (minimum and maximum allowable) parameters of sustainable potential for the loss-free development of agriculture. This allows to identify certain restrictions on the occurrence of destabilization processes in the industry, as well as the manifestation of the crisis in the financial condition of agricultural enterprises [8].

The generalized criterion of sustainable potential of the loss-free development according to the level of financing of production activity of agricultural enterprises is offered to be considered as a complex value. The normative value uses the industry average indicator, which allows assessing the sustainable condition of the agricultural enterprise in comparison with the industry average.

Comprehensive indicators for determining the sustainable level of the loss-free development potential are calculated using the method of dynamic rating assessment. To do this, in practice, when choosing the basis for the rating assessment, the concept of "reference company" is introduced, which has indicators corresponding to the normative minimum value of the efficiency of agricultural enterprises [10].

The dynamics of the studied indicators (intensity of use of financial resources and sources of financing; efficiency of use of financial resources and sources of financing; risks of financing; intensity of financial processes and provision of the loss-free production) confirms the determinism of sustainable agricultural development. In any case, in our opinion, destabilization processes and cyclical changes in the financing of agriculture in Ukraine under conditions of intensity and efficient use of financial resources are complicated in comparison with the analysis of financing risk. Therefore, we approached the sustainable potential of the loss-free development of agricultural enterprises not from the standpoint of identifying financing cycles, but from the point of view of studying the efficiency of economic processes in the industry, as well as determining the intensity of financing of economic entities.

Under ideal economic environment conditions and the achievement of marginal credit intensity for all similar users of the agricultural market and, in particular, agricultural enterprises that generate gross agricultural output and have similar operations to provide sources of financing, should have equal access to credit and equal in- terest rates [7]. On the one hand, the weighted average cost of raising financial resources in commercial banks is important in this process, and on the other hand, the borrower's ability to repay both the amount of debt on financial obligations and interest on borrowed funds under the terms of the loan agreement.

However, on the other hand, the trend of the reverse indicator - lending (calculated as the ratio of GDP of agriculture to the volume of loans to agriculture) is characterized by a decrease in the efficiency of financial resources, rather than deterioration of agricultural financing [11].

Thus, given the general trend of cyclical destabilization processes to ensure the sustainable potential of the loss-free development of agricultural enterprises, it should be noted that its condition has deteriorated significantly due to the protracted political and economic crisis, aggravated debt security and mismanagement of financial resources, whichare available to the latter.

Sustainable potential of the loss-free development of agricultural enterprises according to a differentiated approach to ensuring its sustainable level in the regions determines changes (strengthening, suppression) of factors (finished products, receivables, use of cash and current financial investments, long-term bank loans, shortterm bank loans, government support) on the general level of financial security of the industry. Further research has shown that the increase in the value of one of the factors causes the growth of another and vice versa [9].

Conclusions. Thus, ensuring the sustainability of the potential of the loss-free development of agricultural enterprises should provide strategic directions and a mechanism for their adaptation to the changing environment, preventive and neutralizing measures to minimize risks and threats, achieve long-term financial results. Based on the state of the industry in Ukraine and focusing on trends in the global agricultural market, we consider it appropriate to form the sustainability of the loss-free development of agricultural enterprises on the basis of an aggregate model of production risk management strategy, capital structure management strategy, financial flow management strategy and anti-crisis financial strategy. In particular, on the part of the state, the need to stabilize the level of the loss-free development potential of agricultural enterprises determines: strengthening the internal redistribution of resources between the subjects of the agricultural production market, through the implementation of state policy of financial support for agriculture; promoting the development of economic relations of agricultural enterprises through the spread of leasing services and other alternatives to attract financial resources to agriculture; maximum consideration of the risk of financing and investment activities in agriculture.

It is thanks to the functioning of the mechanism of ensuring the sustainability of the poten- 
tial of the loss-free development, which is based on effective state support of agriculture, it will be possible to restore and maintain the proper level of food independence of the country. Therefore, it is necessary:

- to strengthen the incentive function of taxes, redistribution of public funds in favor of further development of agriculture through the implementation of certain state development programs;

- to spread leasing and other alternative credit forms of attracting financial resources in the agricultural sector; development of microcredit for small enterprises - subjects of entrepreneurial activity in agriculture within the framework of implementation of state programs to support the development of small and medium business;

- to support the activities of small private farms by compensating the interest rate, taking into account the objective need to use long-term and short-term loans, as well as maximum consideration of risks through the development of agricultural insurance;

- to implement the investment and innovation strategy for agricultural development and conducting basic research of a sectoral nature under the condition of budget financing of these processes in the near future.

\section{REFERENCES}

1. Synchak, V. \& Vinska, T. (2009). Orhanizatsiya finansovoyi pidtrymky sil's'kohospodars'kykh tovarovyrobnykiv v konteksti intehratsiyi do SOT [Organization of financial support for agricultural producers in the context of integration into the WTO]. Collection of scientific works of Podolsk State Agrarian-Technical University, vol. 17, pp. 684-689.

2. Trusova, N. (2015). Destabilizuyuchi protsesy v systemi zabezpechennya finansovoho potentsialu sil's'kohospodars'kykh pidpryyemstv [Destabilizing processes in the system of ensuring the financial potential of agricultural enterprises]. Global and national problems of the economy, vol. 2. URL: http:// www.global-national.in.ua. (accessed 20 January 2021).

3. Hryvkivska, O.V. (2006). Derzhavna pidtrymka rozvytku sil's'kykh terytoriy [State support for rural development]. The financial system of Ukraine. Collection of scientific papers, vol. 8, pp. 364-369.

4. Kyzym, M., Zabrodskyj, V., Zinchenko, V. \& Kopchak, Yu. (2003). Otsinka ta diahnostyka finansovoyi stiykosti pidpryyemstva [Evaluation and diagnostics of financial stability of an enterprise]. Kharkov: VD «Inzhek». (in Ukrainian)

5. Prystemskyi, O. (2015). Potentsial finansovoyi bezpeky rozvytku sil's'koho hospodarstva [Potential of financial security of agricultural development]. Tavrichesky Scientific Herald, vol. 91, pp. 313-317.

6. Bazarov, G, Belyaev, S. \& Belyih, L. (1996). Teoriya ta praktyka antykryzovoho upravlinnya [Theory and practice of crisis management]. Moscow: Zakon i pravo, YuNITI. (in Russian)

7. Tanklevska, N. Prystemskyi, O. (2017). Rezervy dlya posylennya finansovoyi bezpeky rozvytku sil's'koho hospodarstva [Reserves to strengthen the financial security of agricultural development]. Kharkov: BiznesInform, pp. 274-280.
8. Natalia V. Trusova, Oksana V. Hryvkivska, Nataliya S. Tanklevska, Larysa A. Vdovenko, Oleksandr S. Prystemskyi \& Svitlana V. Skrypnyk.(2019). Rehional'nyyspekt formuvannya: Potentsial finansovoyi bezpeky $v$ ahrarnykh pidpryyemstvakh Ukrayiny [Regionalaspekt of formation: The potencialof financial safety in agrarian enterprises of Ukraine]. The Asian International Journal of Life Sciences. Supplement 21 (1), pp.169-186.

9. Hryvkivska, O.V. (2011). Finansova bezpeka sil's'koho hospodarstva $v$ rehionakh Ukrayiny [Financial security of agriculture in the regions of Ukraine]. Finance of Ukraine, vol. 7 , pp. 93-103.

10. Hryvkivska, O.V. (2010). Teoretychni pidkhody do vyznachennya finansovoyi bezpeky sil's'koho hospodarstva, Formuvannya rynkovykh vidnosyn $v$ Ukrayini [Theoretical approaches to the definition of financial security of agriculture]. Formation of market relations in Ukraine. Collection of scientific papers, vol. 4, pp. 1060-162.

11. National Bank of Ukraine. URL: http://www.bank.gov.ua/ (accessed 23 January 2021).

\section{БІБЛІОГРАФІЧНИЙ СПИСОК:}

1. Синчак, В. та Вінська, Т. Організація фрінансової підтримки сільськогосподарських товаровиробників в контексті інтеграції до СОТ. Збірник наукових праць Подільського державного аграрно-технічного університету. 2009. Вип. 17. C. 684-689.

2. Трусова Н. Дестабілізуючі процеси в системі забезпечення фінансового потенціалу сільськогосподарських підприємств. Глобальні та національні проблеми економіки. 2015. Вип. 2. URL-адреса: http://www.global-national.in.ua. (дата звернення: 20.01.2021).

3. Гривківська, О.В. Державна підтримка розвитку сільських територій, Фінансова система України. Збірник наукових праць. 2006. Т. 8. С. 364-369.

4. Оцінка та діагностика фінансової стійкості підприємства / Кизим М., Забродський В., Зінченко В. та Копчак Ю. Харків : ВД «Інжек». 2003.

5. Пристемський О. Потенціал фрінансової безпеки розвитку сільського господарства. Таврійський науковий вісник. 2015. Вип. 91. С. 313-317.

6. Базаров Г., Бєляєв С. і Бєлих Л. Теорія та практика антикризового управління. Москва : Закон і право, ЮНІТІ. 1996.

7. Танклевська, Н. Пристемський, О. Резерви для посилення фінансової безпеки розвитку сільського господарства. Бізнес/нформ. 2017. С. 274-280.

8. Natalia V. Trusova, Oksana V. Hryvkivska, Nataliya S. Tanklevska, Larysa A. Vdovenko, Oleksandr S. Prystemskyi \& Svitlana V. Skrypnyk. Regionalaspekt of formation: The potencialof financial safety in agrarian enterprises of Ukraine. The Asian International Journal of Life Sciences. 2019. Supplement 21 (1), P. 169-186.

9. Гривківська, О.В. Фінансова безпека сільського господарства в регіонах України. Фінанси України. 2011. Вип. 7. C. 93-103.

10. Гривківська, О.В. Теоретичні підходи до визначення фінансової безпеки сільського господарства. Формування ринкових відносин в Україні. Збірник наукових праць. 2010. Вип. 4. С. 1060-162.

11. Національний Банк України. URL: http://www.bank.gov.ua/ (дата звернення: 23.01.2021). 